DOI: $10.17951 /$ et.2015.27.226

Daria Bębeniec

\title{
JEZZYKOWY OBRAZ ŚWIATA W SZERSZEJ PERSPEKTYWIE
}

The Linguistic Worldview: Ethnolinguistics, Cognition, and Culture, red. Adam Głaz, David S. Danaher, Przemysław Łozowski, London: Versita Ltd, 2013, 492 s.

Omawiana książka jest zbiorem 24 artykułów, z których większość stanowi rezultat konferencji zatytułowanej Językowy obraz świata czy językowe obrazy światów?, zorganizowanej w Lublinie w dniach 17-18 października 2011 r. Jest to druga z kolei anglojęzyczna publikacja (po książce Jerzego Bartmińskiego Aspects of Cognitive Ethnolinguistics, wydanej po raz pierwszy w 2009 r. w tłumaczeniu Adama Głaza), dzięki której szersze grono czytelników ma możliwość zapoznania się z badaniami prowadzonymi w ramach tzw. lubelskiej szkoły etnolingwistycznej, a w szczególności z koncepcją językowego obrazu świata (JOS) wypracowaną przez Jerzego Bartmińskiego. Do udziału w monografii zaproszono badaczy z różnych środowisk, w tym również naukowców niezwiązanych bezpośrednio z lubelską etnolingwistyką. Wydaje się to odpowiadać zamysłowi redaktorów tomu - Adama Głaza, Davida S. Danahera i Przemysława Łozowskiego - którzy jedną z części wstępu poświęcają kwestiom spornym dotyczącym modelu JOS, jednocześnie zapowiadajacc, że w książce oprócz prac będących eksplikacją czy egzemplifikacją teorii znajdą się również artykuły luźno nią zainspirowane, a nawet wobec niej polemiczne.

To zróżnicowanie zostało także odzwierciedlone w strukturze książki. Po wstępie i artykule wprowadzającym Wojciecha Chlebdy następuje pięć części tematycznych. Pierwsza (The linguistic worldview and the poetic text) zawiera artykuły analizujące językowy obraz świata zakodowany w tekstach literackich. Część druga (The cognitive definition) obejmuje prace poświęcone różnym aspektom definicji kognitywnej. W trzeciej części (The system and beyond) zebrano analizy konkretnych kategorii językowych, natomiast część czwarta (Problems and questions) i piąta (Extensions and inspirations) mieszczą w sobie kolejno teksty o charakterze polemicznym i te pozostające z teorią w luźniejszym związku bądź do pewnego stopnia przez nią inspirowane. Dodatkowo, jak piszą we wstępie redaktorzy, istotnym elementem różnicującym artykuły o charakterze analitycznym jest rodzaj użytych danych, na podstawie których rekonstruowany jest konkretny wycinek językowego obrazu świata. Pochodzą one z systemu językowego, różnego rodzaju tekstów, ankiet oraz danych przyjęzykowych. Chociaż nie stanowią one kategorii 
rozłącznych, ich wybór dostarcza ważnych informacji o tym, gdzie według danego autora należy doszukiwać się językowego obrazu świata.

Artykuł wstępny autorstwa Wojciecha Chlebdy dotyczy roli i miejsca polskiej etnolingwistyki w naukach humanistycznych. Szkicując ponadtrzydziestoletni rozwój tej dyscypliny, od studiów nad tekstami folkloru z użyciem metod strukturalistycznych, z czasem rozszerzonych o badania kognitywistyczne nad pozostałymi odmianami języka polskiego, aż po obecnie realizowany projekt badawczy EUROJOS, zajmujący się językowym i kulturowym obrazem świata Słowian w perspektywie porównawczej, Chlebda identyfikuje pojęcia, które będąc kluczowymi dla współczesnej humanistyki, znajdują się w ścisłym kręgu zainteresowań etnolingwistów. Są to: kultura, pamięć zbiorowa, tożsamość narodowa oraz podmiotowość, badane - zgodnie ze sformułowaniem autora - w ich wersji ujęzykowionej. Nie ma przy tym wątpliwości, że możliwe jest udzielenie pozytywnej odpowiedzi na postawione w tytule pytanie (Czy polska etnolingwistyka może stać się filologicznym filarem humanistyki?). Tego rodzaju zmiana postrzegania etnolingwistyki będzie mogła nastąpić pod warunkiem, że w prowadzonych badaniach będą jednocześnie wykorzystywane dwa konstrukty badawcze - nie tylko językowy obraz świata, ale i pamięć zbiorowa.

Autorzy opracowań zawartych w części pierwszej podkreślają znaczenie literatury w badaniach językoznawczych. Anna Pajdzińska przedstawia kontekst historyczny pojęcia JOS, a następnie przekonująco dowodzi na przykładzie wybranych wierszy Wisławy Szymborskiej, że analiza dzieł literackich powinna uwzględniać utrwaloną $\mathrm{w}$ danym języku interpretację rzeczywistości. Z kolei Irena Vaňková, przyjmując perspektywę fenomenologiczną, twierdzi, że poezja, ze względu na bogactwo zawartych w niej tekstualnych konotacji, ułatwia przyjęcie szerokiej, ponadsystemowej koncepcji znaczenia i tym samym umożliwia badaczowi głębszy wgląd w językowy obraz świata. Swój wywód autorka ilustruje fragmentami wierszy czeskich poetów (Wolkera, Kratochvila, Nezvala i Skácela). Trzy pozostałe opracowania, Agnieszki Gicali, Davida S. Danahera i José Vergary, dotyczą m.in. problematyki nieprzekładalności znaczeń. Artykuł Gicali zawiera propozycję rekonstrukcji obrazu świata przedstawionego w wierszu Identyfikacja Wisławy Szymborskiej i jego angielskim przekładzie autorstwa Clare Cavanagh. Szczegółowej analizie poddano tutaj środki językowe służące budowaniu przestrzeni mentalnych (w rozumieniu Gillesa Fauconniera) i stopniowemu odkrywaniu dwóch przeciwstawnych punktów widzenia. David S. Danaher zajmuje się z kolei pojęciem SVĚDOMí (sumienie) w pismach Václava Havla, porównując je z ang. CONSCIENCE i wykazując przy tym wiele istotnych różnic. Również José Vergara, który analizuje wybrane teksty pisarza eksperymentalnego Daniila Kharmsa z wykorzystaniem aparatu pojęciowego kognitywizmu, wskazuje na znaczącą odmienność pojęć BYĆ i MIEĆ w językach rosyjskim i angielskim.

Artykuły zawarte w drugiej części monografii poświęcono podstawowemu narzędziu analiz w modelu JOS, jakim jest definicja kognitywna. Anna Wierzbicka, podkreślając zbieżność własnych założeń i celów badawczych z koncepcją Jerzego Bartmińskiego, przedstawia eksplikację wiedzy potocznej utrwalonej w znaczeniach polskich słów jabłka i zwierzęta za pomocą naturalnego metajęzyka seman- 
tycznego. Jerzy Bartmiński, wychodząc od pochodzenia, założeń teoretycznych oraz specyfiki definicji kognitywnej, proponuje rozumienie tejże definicji jako tekstu, a w szczególności tekstu kultury. Po pierwsze, definicja kognitywna odznacza się semantyczną i strukturalną koherentnością, po drugie jest zapisem utrwalonej w społeczeństwie wiedzy, przekonań i wierzeń o świecie, a także odzwierciedla system wartości podmiotu mówiącego. Refleksję nad specyfiką definicji kognitywnej, zwłaszcza w odniesieniu do definicji słownikowych, zawierają również dwa kolejne artykuły. W pracy Katarzyny Prorok i Adama Głaza stanowi ona wstęp do rekonstrukcji językowego obrazu żelaza w polskiej kulturze ludowej, udokumentowanej różnymi rodzajami danych, w tym także danymi przyjęzykowymi, natomiast u Stanisławy Niebrzegowskiej-Bartmińskiej jest ilustracją rozważań poświęconych nierozdzielności stereotypów i wartości w językowo-kulturowej interpretacji świata. Z kolei Agata Bielak wykorzystuje definicję kognitywną w praktyce, proponując rekonstrukcję językowego obrazu św. Agaty w polskiej tradycji ludowej na podstawie m.in. danych przyjęzykowych.

Trzecią część monografii rozpoczynają artykuły Marty Nowosad-Bakalarczyk, Doroty Piekarczyk i Doroty Filar. Wszystkie te autorki przyjmują perspektywę onomazjologiczną i opierają swój wywód na założeniach zarówno etnolingwistyki, jak i językoznawstwa kognitywnego. W pierwszym artykule omówiono kategorię ILOŚCI w języku polskim w odniesieniu do rzeczy i zdarzeń i dowiedziono jej umotywowanego charakteru niezależnie od tego, czy wyrażana jest za pomocą wykładników morfologicznych, leksykalnych czy składniowych. Dorota Piekarczyk przedstawia z kolei obraz pojęć TEKST MÓWIONY i TEKST PISANY, utrwalony w języku polskim, wykazując, że przybierają one kształt kategorii prototypowej. Chociaż tekst mówiony postrzegany jest zasadniczo jako proces (zdarzenie), a tekst pisany jako produkt, obie kategorie cechują się nieostrością granic i wewnętrzną niejednorodnością. Co ciekawe, językowy i językoznawczy obraz tych pojęć są ze sobą w dużym stopniu zbieżne. Natomiast opracowanie Doroty Filar poświęcone jest rekonstrukcji językowej konceptualizacji myślenia na podstawie danych systemowych i tekstowych. Szczególną uwagę zwrócono na pojęcie PODMIOT MYŚLĄCY, które stanowi najistotniejszy element narracyjnego modelu myślenia zaproponowanego przez autorkę. Aneta Wysocka, która również opiera swoją analizę na danych systemowych i tekstowych, omawia z kolei językowy obraz pojęcia NIEWOLNIK w ujęciu panchronicznym. Ostatni w tej części artykuł, Małgorzaty Brzozowskiej, dotyczy jednego ze słów sztandarowych polszczyzny, patriotyzmu. Autorka rekonstruuje jego rozumienie, odwołując się do wyników Ankiety Słownika Aksjologicznego z lat 1990, 2000 i 2010, a następnie analizuje językowy obraz patriotyzmu wyłaniający się z dyskursu publicznego prowadzonego na łamach "Tygodnika Powszechnego" i „Gazety Wyborczej” oraz na platformie internetowej Lewica.pl.

W artykule otwierającym czwartą część omawianej publikacji Elżbieta Tabakowska porównuje założenia i metodologię badawczą lubelskiej etnolingwistyki i zachodniego językoznawstwa kognitywnego, wskazując na liczne podobieństwa, jak i różnice między dwoma paradygmatami. Podkreślając zasługi lubelskiej szkoły, a jednocześnie patrząc z perspektywy kognitywisty, autorka zwraca uwagę na pewne problemy, takie jak brak pełnej spójności stosowanych przez polskich bada- 
czy pojęć i terminów czy koncentrację na leksyce, a pomijanie składni. Rolę zdystansowanego, ale życzliwego obserwatora przyjmuje również James W. Underhill, który omawia mocne strony polskiej etnolingwistyki, przedstawiając także swoje wątpliwości. W artykule znajdziemy dodatkowo wstępną charakterystykę własnych badań autora nad pojęciem LUD w wielu językach. Z kolei rozważania Przemysława Łozowskiego dotyczące możliwych wariantów relacji między językiem a kulturą prowadzą do konstatacji, że w programie badawczym Jerzego Bartmińskiego mamy do czynienia z dwoma metodologicznie przeciwstawnymi ujęciami tej relacji (kultura jako jeden z komponentów języka / język jako jeden z aspektów kultury). Kolejny artykuł, autorstwa Adama Głaza, zawiera propozycję operacjonalizacji parametrów WIDZENIA, do czego bezpośredniej inspiracji dostarczyła wcześniejsza analiza tego pojęcia przeprowadzona przez Jerzego Bartmińskiego. W opinii autora, który dla ilustracji swych twierdzeń posługuje się fragmentem książki Wojciecha Cejrowskiego Rio Anaconda, analiza powinna zostać uzupełniona o dodatkowy wymiar - tzw. dystans kognitywny. Natomiast Agnieszka Mierzwińska-Hajnos krytycznie zestawia pojęcia definicji kognitywnej i sieci domen (w rozumieniu Ronalda Langackera) na przykładzie semantyki nazw roślin w języku polskim i angielskim.

W ostatniej części monografii zawarto trzy artykuły, z których pierwszy, autorstwa Enrique Bernárdeza, przedstawia językowo-kulturową analizę islandzkich czasowników sjá (widzieć) i heyra (słyszeć) w znaczeniu epistemicznym. W kolejnym artykule Anna Niderla analizuje autoprezentacyjny wizerunek byłych rektorów Uniwersytetu Marii Curie-Skłodowskiej na podstawie wywiadów zebranych na potrzeby Archiwum Historii Mówionej UMCS. Metodę historii mówionej stosuje w swojej pracy również Wiktoria Kudela-Świątek, która w oparciu o relacje biograficzne Polaków zesłanych do Kazachstanu rekonstruuje językowy obraz zniewolenia.

Na zakończenie warto podkreślić dbałość o szatę graficzną i staranne opracowanie redakcyjne książki, widoczne choćby w licznych wzajemnych odniesieniach w obrębie tomu czy w wieńczących całość indeksie osób i indeksie tematycznym. Na uwagę zasługują także bardzo dobre i spójne terminologicznie tłumaczenia artykułów (część z nich została napisana po angielsku, a część przetłumaczona z polskiego). Biorąc pod uwagę znaczenie koncepcji Jerzego Bartmińskiego we współczesnym językoznawstwie, o którym świadczy udział w prezentowanej monografii znakomitych badaczy z różnych środowisk naukowych, jak również wysoki poziom merytoryczny opracowań, pozostaje podzielić nadzieję redaktorów tomu na jak najszersze rozpowszechnienie osiągnięć polskich etnolingwistów na arenie międzynarodowej. Tym bardziej, że - jak trafnie to ujmuje James W. Underhill (s. 339-340) - po zapoznaniu się z ich badaniami na świat patrzy się inaczej. Żelazo, jabłka i wiele innych pojęć już nigdy nie będą tym, czym były. 